\title{
The Influence of Traditional Chinese Culture in Cultivating College Students' Socialist Core Values
}

\author{
Hanyue Kang ${ }^{a}$, Fuxue $\mathbf{L i}^{\mathrm{b}}$ \\ Yingkou Institute of Technology, Yingkou 115014, China \\ a 739296846@qq.com, ${ }^{b}$ lifuxue119@163.com
}

Keywords: Socialist core values; Cultivation; College students; Chinese traditional culture

\begin{abstract}
The socialist core values is the important thought of our party and state, which can not be separated with two thousand years of history of outstanding traditional culture, is the crystallization of Chinese traditional culture, vigorously carry forward the essence of traditional culture, enhance students' understanding of Chinese civilization, establish a correct spirit of patriotism, and constantly strengthen reform and innovation, and actively guide contemporary college students to form a correct and positive socialist core values.
\end{abstract}

\section{Introduction}

Social ideology could be fully represented by socialist core values. Without correct guidance from socialist core values, social development will lose the direction. While the cultivation of socialist core values should be established based on the inheritance and promotion of traditional Chinese culture, which would in turn continually sublimate profound traditional culture. College students symbolize the future and hopes of country and their core values, ideals and beliefs even leave direct impacts on the future development orientation of the country. As a consequence, socialist core value education is the key and difficult points of contemporary college student ideological and political education.

\section{Dialectical Unity of Traditional Chinese Culture and Socialist Core Values}

\subsection{Traditional Chinese Culture as the Thought Source of Socialist Core Values}

“Three advocacy" guideline is strongly proposed in the Report of the 18th National Congress of CPC. The main purpose of the guideline is to propel the construction of socialist core values. "Three advocacy” starts from multiple dimensions to specify the core value pursuits of the country, society and citizens [1]. Strengthening college students' traditional Chinese cultural education has significant functions in guiding college students to cultivate correct view of life and socialist core values. Throughout the everlasting development history of Chinese civilization for five thousand years, excellent traditional culture deposits still leave influences on Chinese people generation after generation in many aspects. Many core elements in traditional culture possess universality characteristics. For instance, "honoring promise and neighborliness" emphasizes the amicability between people; "unity of heaven and man" emphasizes the natural harmony between man, nature, heaven and land;"serving people worldwide as one's duty" emphasizes individual sense of social responsibility, "virtue humanity", and "kindness". Value concepts such as "mutual help among neighbors" have eternal and lasting charms and always flow in the blood of the Chinese nationality. They have integrated into the spiritual genes of every Chinese people, penetrated into the potential ideology and strongly interlinked with the intrinsic spirits of socialist core values out of same origin.

\subsection{Socialist Core Values as Inheritance and Promotion of Traditional Chinese Culture}

In nature, the basic contents of "three advocacy" socialist core values symbolize the condensation of Communist Party members for traditional Chinese cultural essence during over ninety-year 
historical practice, and the inheritance and sublimation results of traditional Chinese culture according to the epochal conditions of comprehensive deepening reform, thus fully revealing Chinese Communist Party's innovative and creative spirits with the advancement of time. It is the achievement made by the Communist Party of China through adhering to ancient traditions and making innovation with differentiated acceptance or rejection according to the development and changes in contemporary times". [2] During the construction process of socialist core value systems, the Communist Party of China always persists in various guidelines, insists basic thoughts as guiding thoughts, commands the core of traditional Chinese culture, keeps up with social development, makes lasting observation and excavation on traditional culture so as to inherit the essence of traditional Chinese culture and stimulate traditional Chinese culture's new vitality and vigor.

\section{Significant Meaning of Promoting Traditional Chinese Culture to Cultivate College Student Socialist Core Values}

\subsection{Traditional Chinese Culture as the Main Content of College Student Socialist Core Values Education}

Profound national culture accumulated and inherited during historical development process goes through every aspect of human values, customs and moral codes. A multitude of excellent traditional Chinese culture concepts such as "self-improvement”, “patriotism”, "filial piety”, "people-orientation”, "honesty and trustworthiness" run through overall socialist core value system. Higher education unceasingly facilitates the advancement of the society. At the same time, higher education cultivates high-quality professional talents from generation to generation, therefore making great contributions to the development of China, speeding up the transformation as a modern country and finally realizing cultural regeneration of the great nation. Consequently, high education process should always carry out socialist core values education and make it exert positive and effective promoting functions. In this sense, cultivating contemporary college students' socialist core values is to teach students to recognize the unique creative and spiritual core of Chinese culture, know about the development origin and historical orientation of Chinese culture, boost students' cultural confidence and theoretical confidence, guide students to establish and persist in correct historical viewpoints, national viewpoints and cultural viewpoints, urge students to foster traditional virtues of the Chinese nation represented by "patriotism", "modesty and self-cultivation", "honesty and trustworthiness", "integrity and self-respect", "shame of consciousness and righteousness" as well as establish college students' socialist core values in line with the national, social and individual values advocated by the core values.

\subsection{Traditional Chinese Culture Offers Education Method to the Cultivation of College Student Socialist Core Values}

Among the education concepts in China, numerous eminent traditional Chinese cultures could effectively help college students shape correct core values. The basic teaching concept characterized by "being as role models" and "teaching by words and deeds" requires educators to value their own speech and actions and set themselves as examples to students; the prescriptive education methodology characterized by "enlightening with reason and emotionally moving" demands teachers to infuse more emotions to positively guide students and maintain favorable communication relation; the individualized teaching method characterized by "objective-orientation and individualization" requests teachers to have detailed understanding about the basic conditions of students and conduct corresponding teaching work based on students' characteristics; the practice teaching methodology which pays equal attention to theory and practice endeavors to apply moral awareness in practice and combine theory with practice; "at present, we have to combine contemporary college students' socialist core value education with specific teaching methods, strongly carries forward traditional Chinese virtue education in political classes, elevate students' moral quality, and try to cultivate elites with literacy and education. Meanwhile, all-above mentioned education methods should be applied in 
practical teaching to instruct college students to shape correct values, make self-improvement, form noble sentiments, mould ideal personality and realize healthy personal growth under the guidance of socialist core values.

\section{Choices for Promoting Traditional Chinese Culture and Cultivating College Student Socialist Core Values}

\subsection{Fully Exerting Main Channel Functions of Teachers' Teaching}

A key point worth of mentioning here is to fully exert the main channel function of teachers' teaching. Teachers from universities are supposed to change traditional teaching mode and teaching concepts, regard traditional Chinese culture as the entry point, closely center around socialist core values to develop education since ancient times, add the interests and efficiency of teaching, and consolidate college students' recognition degree towards “three advocacy”. On the part of students' value orientation guidance, construction of teaching staff team is of great importance. Every speech and deed of teachers would generate imperceptible impacts on students. As a result, teachers should offer favorable value and cultural value orientation to teachers through practicing excellent traditional Chinese culture. Teachers should possess profound cultural temperament, righteous values, and decent personality quality. On the other hand, they should positively act as the examples of students in both teaching and social activities and instruct students to have appropriate recognition towards the essence of traditional culture by way of practical personal actions. In a word , they should "implement people-oriented" education concept, reinforce the pragmatism of ideological education, think over the needs of students, examine how to make ideological education authentically touch the inner mind of students, refuse to simply infuse extensive moral teachings, observe students' thoughts as the role of instructor and accordingly precisely guide students to build positive socialist core values.”

\subsection{Building Traditional Cultural Atmosphere and Exerting Edifying Influences on University Campus}

As is well known, university campus has important influences on students' learning and life and exerts educative guidance functions on students' growth process. While at present, many universities have already incorporated traditional culture education into campus construction and use diverse means to mould traditional cultural atmosphere. Schools expect to positively guide students to form correct socialist core values through this means, and integrate it students' practice activities. Universities could organize students to join in classics reading, moral forum, cultural lecture, competition, exhibition, performance and other series of activities; refer to academy teaching mode to conduct traditional Chinese cultural learning activities such as classics reading and memorial activities on important festivals such as Youth Day and CPC Founding Day; utilizing major folklore celebration galas such as Dragon Boat Festival and Mid-Autumn Festival to popularize cultural concepts and excavate rich education resources contained by festivals and important events; add traditional Chinese culture into the teaching syllabus as a selective course and conduct examination in term end to boost student initiative; greatly support ideological and thinking lesson teachers' research projects and encourage them to study relevant research topics concerning traditional Chinese national culture with granted fund; continually add teaching materials related to traditional culture and regularly hold campus cultural activities to make college students have deep insights into the essence of traditional Chinese national culture and realize imperceptible driving forces.

\subsection{Highlighting Important Functions of Social Practical Activity Education}

Social practice is a significant channel to upgrade college students' ideological temperament and cultural innovation awareness, and meanwhile a basic means to foster college students' socialist core values. Through continually organizing all sorts of social practice activities, students would have more new understanding about things, combine theory with practice and finally realize the purpose of 
using theory to guide practice and using practice to test theoretical knowledge in turn. While during the education process, universities have to infuse traditional Chinese culture into the mind of every student. In such conditions, universities need to use appropriate means to guide students and attempt to organize some social practice activities concerning the internship and life of college students, such as organizing students to join in social labor in villages, and contribute to social public welfare cause in old people's home and orphan asylum; launch activities in promotion of traditional Chinese culture; encourage students to boost their patriotic awareness via personal experience and amplify sense of social responsibility to some extent so as to combine learning and thinking, theory and practice.

\subsection{Seizing the Initiative of Network Public Opinion Guidance and Enriching Cultivation Forms}

In contemporary times with increasingly prominent globalization tendency, college students must have correct value judgment criteria after fostering correct judgment capacity on network information. While positive ideological guidance enables teachers to help students form correct judgment capacity, independent thinking capacity and problem-solving capacity. Only in this way could students realize stable personal growth in the future. As for students' ideological education work, universities have the responsibility to keep up with times. Hence, how to guide students to use various network resources, realize positive guidance effects and help students establish positive socialist core values is the most urgent task nowadays. To be specific, it advocates campus network culture construction and management, and tends to use the network means to gather students on the network, regularly upgrade promotion videos and relevant traditional Chinese culture education lecture videos and allow students to learn traditional Chinese culture in column which integrates image-text, sound, image and animation. In addition, it is also feasible to utilize present popular communication software to improve students' comprehensive capacity, such as MicroBlog, QQ and other communication means, develop interesting traditional Chinese cultural network products, further use such resources to mobilize Party members and student associations to initiate civilization online surfing activities, lead students to practice morality online and perform legal social responsibilities.

\section{References}

[1] Yuan Z. On the Positive Role of Public Art Education in the Formation of College Students' Socialist Core Values[J]. European Journal of Marketing, 2015, 31(2):134-149.

[2] Shang H, Jin T, Liu W. Is harmony still in the local socialist officials' hearts: An exploratory assessment of Chinese county and department level officials[J]. Chinese Management Studies, 2016, 10(3):480-509.

[3] Wang G T L B Z. Illustrating assessment: how Hong Kong university students conceive of the purposes of assessment[J]. Studies in Higher Education, 2013, 38(7):1037-1057. 